INÖNÜ ÜNIVERSITESI

HUKUK FAKÜLTESI DERGISI
INONU UNIVERSITY

LAW REVIEW

ISSN: 2146-1082 e-ISSN: 2667-5714

İ ÜHFD - InULR

Otobiyografi

DOI: https://doi.org/10.21492/inuhfd.584678

\title{
Prof. Dr. Fikret EREN
}

Kahramanmarakâa avukat bir babanē ộ lu olarak 1935 yēēêda dünyaya geldim. 1958 yēēèda Ankara Üniversitesi Hukuk Fakülttesiôni pekiyi dereceyle bitirdim. 1967 yēēèda doçent oldum. 1975 yēēênda profesörlük unvanēiēald đৈtan sonra uzun yēlar Ankara Üniversitesi Hukuk Fakültesinde öj retim üyesi olarak çalēêēn. 2002 yēēèda yaK haddinden emekli oldum.

Ben hayatta bakarēēolmayēku 4 ilkeye baĵ lēerum: Birinci ilke, hayatta, yani gelecekte ne yapacaj $\bar{\oplus} e \bar{e}$ ne olacầ $\bar{e}$ ē düKinmek; ikinci ilke, bu düKinceler içinde seçenekler oluKurmak; üçüncü ilke, büyük düKinüp büyük isteme kapsamēêda bunlardan birini seçmek; dördüncü ilke de, bu seçimler sonunda bunlarēgerçeklekirebilmek için evvela çok çalērmak. Çalēermayēda hafta içi 5 güne 1 gün daha ekleyerek 6 güne ç đararmak. Her gün 10 saat civarēenda çalē̌rmak. Haftada 6 gün,

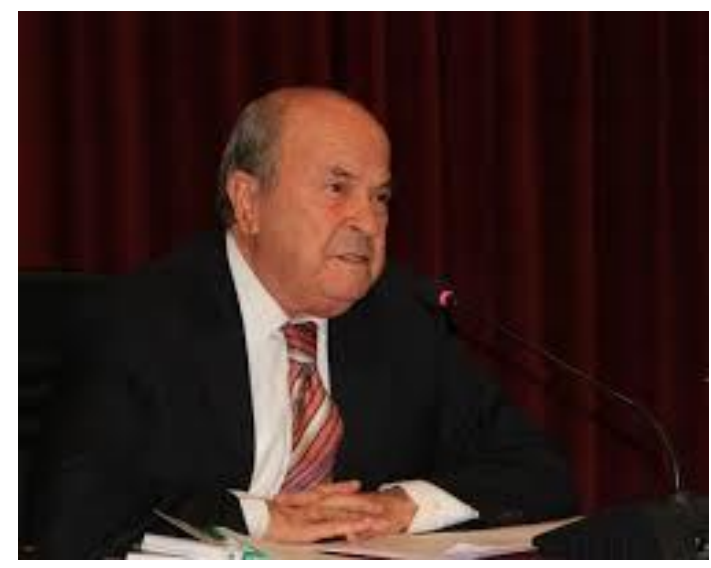
günde 10 saat çalēermayē bir yöntem içinde, yani emê̂ i yararlēsonuç verebilecek verimli, üretken biçimde kullanarak

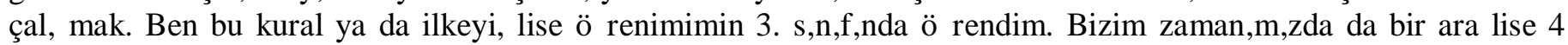
yđ̄ēe 3. yđ̈da hukukçu olmaya ve hukuk öĵ renimimi de, Ankara Üniversitesi Hukuk Fakültesinde yapmaya karar verdim. Ankaraộē bakkent olmasēe hükümet ve Türkiye Büyük Millet Meclisinin orada bulunmasē daha yeni ve modern bir kent olmasē beni Ankaraôa iten bakēẹa sebeplerdi. Nitekim, liseyi bitirdî̄ imde Ankara Üniversitesi Hukuk Fakültesiône ilk tercihim olarak gelip bakvurdum. O zamanlar liseyi bitirdikten sonra üniversiteye girebilmek için ñolgunluk sē̄av $\vec{\oplus}$ denilen bir sệavē da bakarmak gerekmekteydi. O zamanlar henüz ÖSYM kurulmamēđē Sözünü ettî̀ im tarih 1954 yëēidi.

Ben Ankara Üniversitesi Hukuk Fakültesiône 1954 yēēEylül ayēenda kaydoldum. Ankarâ̂la bir kiki hariç benim ve ailemin tanēelè ēhiç kimse yoktu. Özellikle de bir akrabamēe yoktu. Tek tanēelêêēe kiki, Kahramanmarakôē

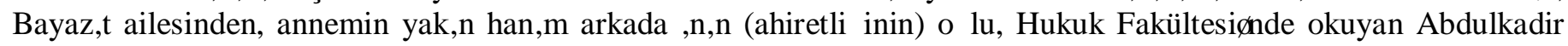

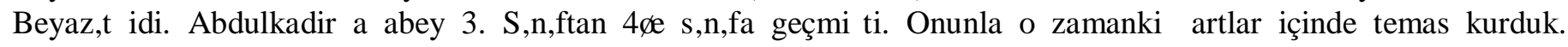
Saĵ olsun ben Ankaraộa geldî̂ imde beni çok güzel bir kekilde karkđ̈adẹ kabul etti, elimden tuttu, mükemmel bir aj abey olarak beni Ankara Üniversitesi Hukuk Fakültesiône kaydettirdi. Zaten o yë liseyi de olgunluj uk sēmavēella birlikte Haziran ayēida pekiyi derece ile bitirdî̄ im için herhangi bir sēnava girmeksizin böylece Fakülteôye kaydoldum.

Hukuk Fakültesiônin arkasēnda da Hukuk Yurdu vardē Neredeyse Fakülteôde ders zili çaldêēenda Yurtâan duyuluyordu. Fakülte ile Yurt arasēidaki mesafe yaklakß 100 metre civarēidaydē Abdulkadir aĵabey bu Yurtâa

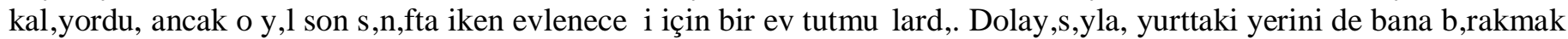
istiyordu. Bu amaçla birlikte Yurt Müdürlüj üne gittik, beni yönetime takdim etti ve yurttaki yerinin bana verilmesini istedi. Yönetim de bu istêি i kabul ederek beni Hukuk Fakültei Yurduôna kabul etti. O zaman söz konusun yurdun odalarē büyük koĵ uklar halinde, karyolalarē da ranzalar (altlēüstlü) keklindeydi. Böylece aynē gün hem Hukuk Fakültesiône hem de Hukuk Yurduôna kaydēn yapēmēđtēve çok sevinmik çok mutlu olmukum.

Lisede belki her delikanlē her genç gibi kiir yazardēn. Benim de her genç gibi romantik bir yönüm oldụ̂ u için

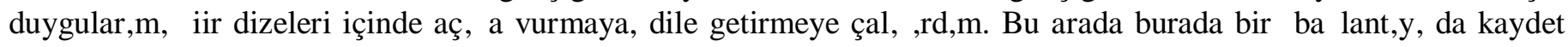
istiyorum. Babam, hukukçuydu, avukat idi. Belki de hukuk öĵ renimi yapma arzum buradan doĵ muku. Ķ̣kokulda, ortaokulda okurken yazlarēbabamēē ofisine (yaz̄̄anesine) giderdim. Ofiste yazēmakinalarē(daktilolar) vardē Orada daktilo kullanmasēèēöôj rendim. Babam, bazen dava dilekçelerini bana yazēê̄ēē kendi söyler, daktiloda ben de yazardēn. Böylece daha çocuk yakarēnnda 10 parmak olmasa da iki parmakla daktiloda yazmasēèèda öj renmiktim.

Kasēn ayēgelmik fakülte öj renime açēmēètē Gündüzleri fakülteye gidiyor, hocalarēnēdinliyor, not tutuyor, akkamlarē da yurtta notlarēnē gözden geçiriyor, ders kitaplarēida ilgili yerleri okuyordum. Yoĵ un bir çalēđma ve öj renme içindeydim. Henüz bir iki hafta geçmiki ki, hayatēnda, ruh dünyamda büyük bir deĵ ikikliĵ in olduj unu 
hissettim. Bir de baktēn ki, hukuk artđ benim için kïrden daha sēeak, daha güzel, daha etraflēbir yakam ve iklim

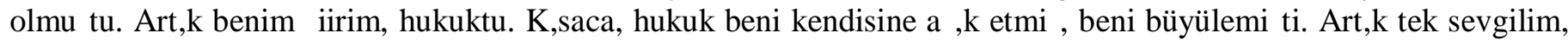
tek Kiirim vardē o da hukuktu. Kূরe böyle duygu ortamēèda o mütevazi kairlị̂imi, hukukun üstün büyüsü ya da

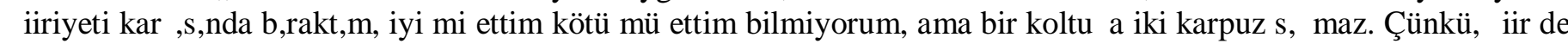

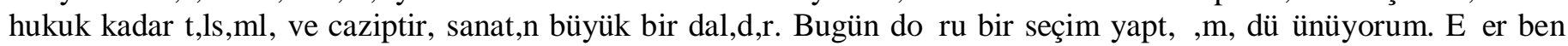

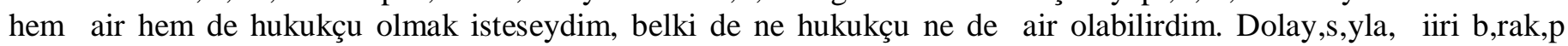
hukuku seçtim. Böylece, hukuk benim Kiirim, sevgilim, her Keyim olmuku. Onu seviyordum, ondan ayrēdệ ēn zaman onu özlüyordum ve ikim varsa, yemek yiyorsam, bir dostla sohbet ediyorsam, maça veya sinemaya gitmiksem, mümkün oldûj unca çabuk gelip hukuk kitaplarēnla tekrar bulukmak, özlemimi gidermek istiyordum.

Böylece ben haftada 6 gün, günde 10 saat çalēan bir öj renci olmukum. Sonra da bu dengeyi bozmadēn, bütün hayatēnca ortalama günde 10 saat hukukla ilgilendim, çalēermaya devam ettim. Demek ki, daha 1 . sēêđta günde 10 saat hukukla ilgilenmeye baklamētēn.

Bizim öĵ rencilik zamanēnēda Ankara Üniversitesi Hukuk Fakültesiônde ñissü mizanò denilen zor, karmakß̈k bir sẹ̄av sistemi vardē Biz öj renci olarak her yē 6 dersten sēmava girerdik. Bunlardan kurôyla seçilen ilk 2 ders, eleme, yani baraj dersiydi. Bu iki dersten yazēēēẹav olurduk ve ancak bunlardan bakarđ̄ēoldụ̂ umuz takdirde, dî̄ er 4 dersten de sözlü sẹ̄av olurduk. Bu 4 dersin sözlü sẹ̄avēia aynēgün birbirini izleyen zamanlarda girerdik. Bu 6 dersten en az geçer 5 puan almak kartēella toplam 42 puan tutturmamēe gerekirdi. 42 toplam puanē6 derse bölersek, her dersten ortalama 7 puan almamēe gerekirdi. 7 (bugünkü sistemde 70) sēenav puanē iyi dereceyi ifade eder. Demek ki,

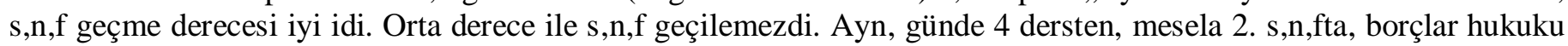
genel, ceza hukuku genel, idare hukuku ve hukuk tarihi gibi 4 ayrēbrankaki dersten aynēgün sēmava girip ortalama 7

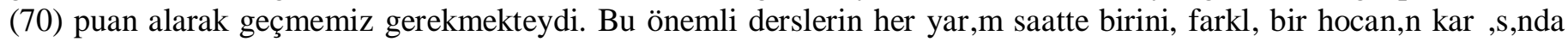
sēiava girerek bakarmak gerekiyordu. Bu derslerden birinden 5âen (50âlen) düKik puan alēesak, dördünden de kalmēe

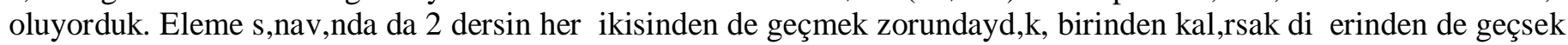

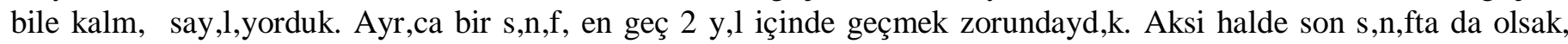
fakülteden kaydē̄ēe siliniyordu yani fakülteden atēēerduk.

Tesadüfe bakēi ki, ben bu sistemle mezun olduj um fakültemde 1967 yēēenda doçent oldum ve doçent olarak profesörler kurulunda oy verdim ve bu eleme sistemini kaldēeß̄k. Adēñissü mizanò olan ve Fransa@̂lan alēian bu sistemi kaldēan kikilerden, ö̂j retim üyelerinden biri de ben oldum. Ondan sonra bugünkü normal sistemi getirdik.

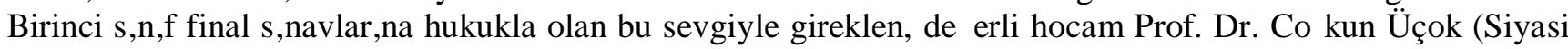

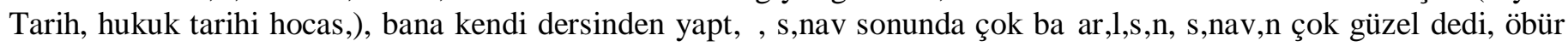

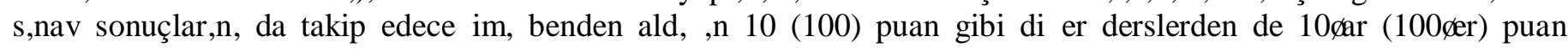
alēesan, sana kimdiden fakülteyi bitirince burada asistan olmayēdüKinmeni, her yē sēēēēēëüstün bakarēla geçip mezun oldụ̂ unda bu Fakültede asistan kalmanētavsiye edecể im dedi.

Ben, bu söz ve tavsiyeyi duyduĵ um ana kadar gelecê̂i için çok mütevazēdüKinen bir hukuk öĵ rencisiydim. Babam Kahramanmarakôa avukattē Hukuk fakültesini bitirip Kahramanmarakố gidip avukatlē stajēēēyapmayēve daha sonra babamēê ofisinde avukatlệ a baKlamayēdüKinmekteydim. Ne var ki, Hocamēi bu söz ve tavsiyesi daha o anda beynimde bir bomba gibi patlamēজ bütün hayat plan ve projem deĵ iкmik beni müthikmutlu etmiki.

Benim Kahramanmarakôē Fikret Eren olarak fakülteyi bitirdikten sonra Kahramanmarakôa geçireceji im, kuracâj ēn dünyamēè yerini, Ankaraôla Fakültemôte bir asistan, bir akademisyen olarak yapacaĵ ên hizmet akkē almēèè Yani, çok çabuk Ankaraốa, fakültede asistanlệ a karj olmukum.

K̦eride Ankaraôla hocam gibi bir gün bir profesör olacaĵ ēnē onun gibi öĵ rencileri sēenav yapacaĵ ên günleri, onunla konuKurken bir yandan da ikinci bir akẻla, dimâj la, rüyayla düKinmeye baklamēđē̄n. Ve sệav bitince gittim,

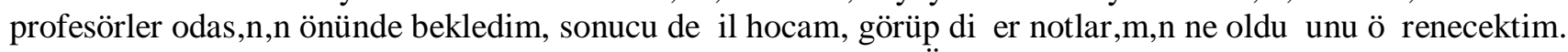

Bekledim akkam saat 18-19 oldu, hocalar çđরtē Cokkun Üçok hocam beni gördü, gel gel Fikret dedi. O gün girdî̄ imiz 4 sözlü dersten 4 tane 10 (100 puan) aldēe dedi. Zaten eleme ders puanlarên da yüksekti Hocam, sen mezun olunca Fakültede asistan kal ama senden 2 keyi derhal deĵ iktirmeni istiyorum dedi. Bir, daha önce içeride sordum lisede yabancēdil olarak Fransēea okuduĵ unu, ancak çok zayēe olduĵ unu söyledin. Fransēeaôēëĵ renip gelikirmen gerek. Bir de Ku KahramanmaraK Kivesini bēekēe, K̦tanbul kivesini öĵ renmen lâzēn, bu kiveyle asistan olunmaz, seni asistan almayē dedi. Hocamē her iki telkin ve tavsiyesini emir telakki ettim.

Derhal Kahramanmarakồ gidip, Fransēèca öj retmenlerinden Fransēeca öj renmeye baKladēn. Onu da bana yine Cokkun Hocam ku cümlelerle söylemiki; ñKahramanmarakđ̂ē Fransēca ö̂িretmenleri vardēe, onlar da yazēı yalnēè̄ēlar, arkadaK ararlar, senin gibi bir hukuk öĵ rencisi gidip onlara, hocam bana Fransēeca öj ret derse, hem memnun olurlar hem de bir arkadak bulmuk olurlar. Hatta seni evlerine çaj $\bar{e} \bar{e} l a r$ sana orda bir sürü ikramda bulunurlar, üstelik ders ücreti de istemezler.ò.

ķivemi düzeltme yolu olarak da Hocam, o zaman televizyon henüz olmadêē yalnēe radyo bulunduĵ u için ñadyodan haber bültenlerini dinlememiò istemiki. Radyoda spikerler tarafēedan ö̂̂ len 13, akkam da 19 haberleri okunurdu. Bu haberler, güzel ve dộ ru bir K̦stanbul aksanēlla okunurdu. Hocam, ñoradan haberleri dinlemek suretiyle kiveni düzeltò demiki. Bir de, ñsonbaharda Ankaraôaa geldî̂ inde devlet tiyatrolarē̄a git orda da sanatçđar güzel bir Türkçe aksanējla konukurlar, onlarēda dinle ve yararlanò demiki. 


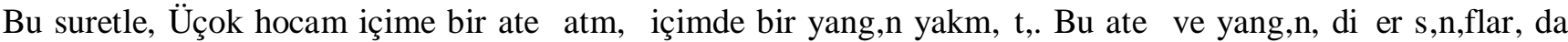
birinci sēēẹta oldụ̂ u gibi birincilikle geçmek, neredeyse fakülteyi birincilikle bitirmekti. Böylece, ancak bakarēēve yabancēdil bilen bir kimse oldụ̂ um zaman asistanle sệ̂avēēèbakarma kansēen doĵ muKolabilecekti.

Hocamdan aldệ ên bu güç ve arzuyla gecemi gündüzümüze kattēn, bütün sēēēlarēo dereceye veya o dereceye yakē derecelerle geçtim ve pekiyi derece ile fakülteden mezun oldum. Daha önce son sēiêtta ticaret hukuku dersimize geldî̉i için çok deĵerli hocam Ali Bozerđ̂e tanēxma ve konukma imkânēn olmuku. Bozer hocama, ticaret

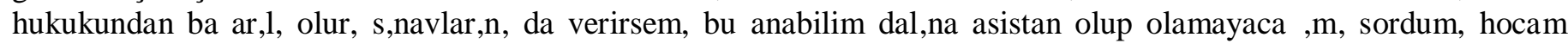
bana, ñsēavlarda bakarēēoldụ̂ un takdirde, seni asistan alēēènò demiki.

O zamanlar daha fakültede öj renci iken (lisans öĵ rencisi olarak) 3 yë 3 seminer yaparsan, asistan olduju unda doktora çalēermalarēa doĵ rudan doĵ uya baklayabiliyor, böylece bir yē kazanmēđ oluyordun. Ben, bu kuralē da öj rendî̉ im için 2, 3 ve 4. sēē̄llarda birer dersten seminer yapmēđēen. Böylece daha fakülte öj rencisiyken bilimsel arakēma ve yazmayēkēmen de olsa yavaKyavaKöĵ renmeye baklamēēen. Bu da faydalēve orijinal bir yoldu.

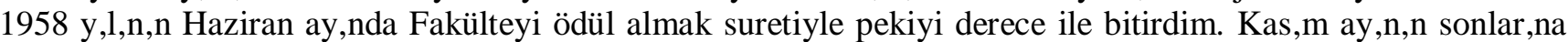

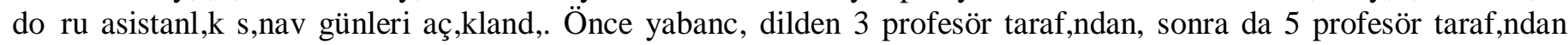

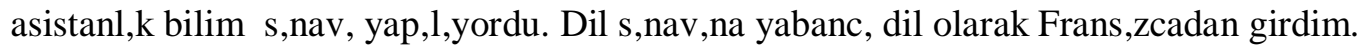

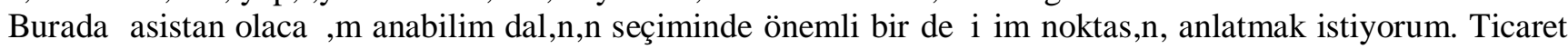
hukuku anabilim dalēida açēacak asistanlę kadro ve sēiavēia bakvurmak için fakülteye geldî̉ imde, Osman adlēbir sēēé arkadakēna rastladēn. Osman, Medeni hukuk hocalarēnēèdan Prof. Dr. ķakir Berki hocam ile çok iyi görükirdü. Osman, bana hayrola Fikret sen fakülteyi bitirdin, senin kimdi Kahramanmarakâa olman gerekirdi, ne ikin var burada diye sordu. Ben de Osmanô, asistan olmak istiyorum onun için buradayēen dedim. O da bana, kime asistan olacaksēn diye sordu. Ben de sē̄avēkazanēsam deĵ erli ticaret hukuku hocam Ali Bozer⿳̂̉ dedim.

Bunun üzerine Osman bana, hayēe olmaz, gel ben seni k̦akir Berki hocamēa götüreyim, dedi. Demek ki, kader, alền yazê̄n öyleymik hiç itiraz edemedim Osmanĉ̣̂̄ bir tek cümlesi beni sanki hipnotize etmiki, O önde yürüdü, ben de onu takip ettim ve böylece, k̦akir Berki hocamēēề odasēia girdik.

Ķakir hocam, tabii fakülteden hocamdē Osman, ñḳakir hocam, Fikret Kahramanmarakđ̂ēēê, asistan olmak istiyor, onu size getirdim, gerisi size aitò dedi. Hocam, bizi çok iyi karkǣadēve bana hemen, yabancēdilin var mē evladēn diye sordu. Ben de biraz Fransēea biliyorum dedim. Hocam hemen bir Fransēer hukuk kitabēēeraftan alarak rastgele seçtî̄ i bir sayfayētercüme etmem için bana verdi. Ben de söz konusu sayfayētercüme ederek hocama verdim.

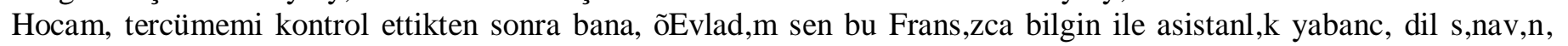

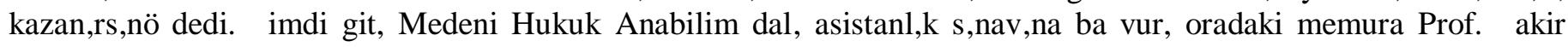
Berkiônin kürsüsüne bakvurduj unu söyle, yabancēdil sẹ̄avēile medeni hukuk bilim sēeavēèèbakarēlla verirsen, benim asistanēn olursun. Ayrēè sēelavlarēkazanēecaya kadar da bir daha ne beni gör, ne bu bu odaya gel, sana bakarēar diliyorum dedi.

Hocamē̄ karekteri öyle idi, benim kendi gücüm ve bilgimle asistan olmamēe geleceĵ im yönünden gerekli görüyordu. Nitekim öyle de oldu ve ben sē̄avlarēê̄ê her ikisini de bakarēlla verdikten, asistan olarak atandēktan

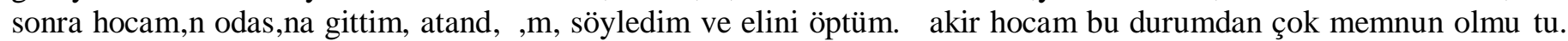
Hemen bana odasēèda bir yer gösterdi, ñBundan sonra buraya otur evlat, kimdi seninle beraber ilk çayēēèēiçelim, seni tebrik ediyorumò dedi. O zamanlar, siyasal bilgiler mezunlarē toprak hukuku, roma hukuku, adli tē gibi 3 dersten fark sēèvēè bakarēella verirlerse, aynēzamanda hukuk mezunu da sayēēerlardē Ancak, hukukçular bu durumdan hiç memnun deĵ illerdi. Çünkü, böylece bir siyasal bilgiler mezunu kolayca hem siyasal hem de hukuk mezunu oluyordu. Hocam, demek ki, bakarēndan memnun olmuk olmalē ki, bana, ñBen Adalet Bakanlệ̂̄a gidiyorum, toprak hukuku fark sē̄avēvar, siyasal bilgiler mezunlarēbu dersten sēelava girecekler, onlarē her biri zaten senin baban yakēêda ya vali veya kaymakam ya da emekli olmuk bürokrat, sen sēiavda gözcülük yap, zaten 1 saatlik bir süre veriyorum, hepsi 20-25 kikiler dedi ve iki bana bēaktēgitti. Ben de sēlavēyaptên sonra hocam gelince sềlav kâj ềlarēēekendisine teslim ettim.

Asistan olunca beni tebrik eden, sonradan birlikte eKya hukuku kitabēēēyazdêēen, deĵ erli hocam Kemal Tahir Gürsoy ile karkēakēēn. ñEvlat asistan olmuKsun memnun oldum, ö̂̀ rencimdin seni tanēēen, bakarēēbir öĵ rencisin. Yalnē sen yabancēdil olarak Fransēecadan girmiksin. Fransēecayla medeni hukuk olmaz. Derhal bugün Almancaôja

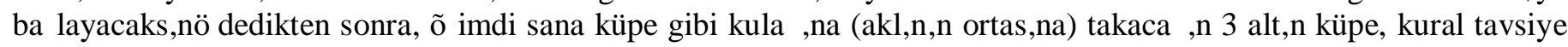
ediyorum. Bunlardan biri, doçent oluncaya kadar evlenmeyeceksin. Çünkü evlendî̄ in takdirde ekin de seninle yurtdēê̄e gelir, çocuk veya çocuklarēêe da olur, Almanca öj renemezsin. Almanya sizin için bir Türk adasēolur, bu

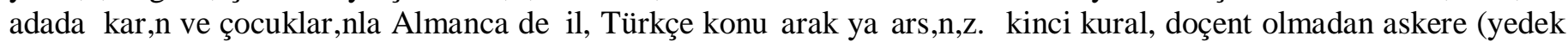

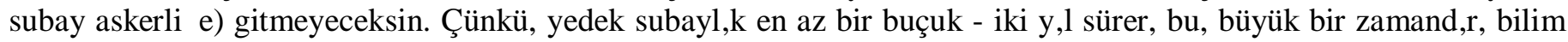
hayatē̊ büyük bir kesintiye uĵrar. Bilimsel yoĵunluĵu kaybedip, çalēermaya ve ö̂̂renmeye ara vermek zorunda

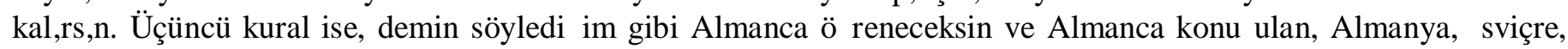
Avusturya gibi bir ülkeye gideceksinò dedi.

Bu üç tavsiyeyi de harfiyyen yerine getirdim. Bu bâ̂ lamda, 1958 Kasēnn ayēenda açēan Medeni Hukuk asistanlę sēenà̄èēbaKarēlla verdim ve asistan oldum. Ertesi gün Almanca öĵ renmeye baKladēn. Günde en az 4 saat Almanca çalēēerordum. 
1959 Temmuz ayēê̄en sonuydu. Yaz tatili çoktan baklamēđēe Fakültede hiç kimse yoktu. Hocalar da asistanlar da tatile gitmiki. Ben Almanca ö̂̂ reniyordum ve de Ölüme Bẩ lēTasarruflarē̄ Kptali Davasēè doktora tezi olarak seçmikim. Tam o yе̄ K̦iviçreâle de Almanca, ölüme bậ lē tasarruflarē iptali davasē diye bir doktora tezi yayēnlanmēètē $O$ tezi hemen ödünç (ariyet) olarak Kșiçreâlen getirttim. Hem konuyu bilimsel olarak daha derinden öj reneyim hem de Almancaêlan Türkçeye çevirerek Almanca çalēđmalarēnn da bilimsel alana girsin istiyordum.

Bir de küçük daktilo almēêên. Onunla her gün fakültede, hocam odasềnda oturmama izin verdî̉ i için çay yap $\bar{\varphi}$ 10 saat medeni hukuk derslerine ve Almancaya çalēēèjordum. Aradan 8-9 ay geçmiki, arț az da olsa Almanca hukuk eserlerini tercüme etmeye baklamēđền. Bu tercümeleri henüz hiç kimseye de göstermemiћim.

Fakültemizde en iyi Almanca bilen hocamēe Prof. Dr. Kudret Ayiter idi. Hocamēe, Fakültemizde çok deĵ erli bir insan ve bilim adamēèdē Annesi Alman asēlēbir Türk vatandakēoldû̂ u için kendisi Almanlar gibi çok iyi ve düzgün Almanca bilir ve konukurdu. Temmuzâın son günlerinden bir gündü, belki de Kudret hocam da çalēermak için

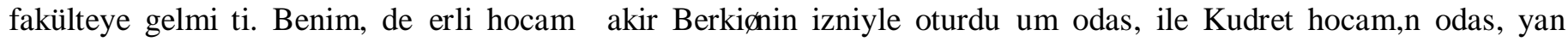

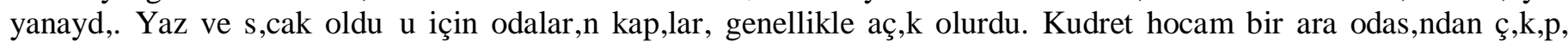
benim odamēi önünden geçerken oda da beni gördüĵ ü için bana, ñNe o Fikret sen de mi fakültedesin, daktilo da ne yazējorsun? ò diye seslendi.

Ben de, doktora tezimin konusuyla ilgili Ķviçreâle yeni bir doktora tezinin yayēnlanēelê ềę bu tezi ariyet yoluyla Ķsiçre Kütüphanesinden getirttî imi ve hem bu konudaki akademik bilgimi hem de öj renmeye bakladệ ēm Almancamēgelikirmek için bu tezi tercüme ettî̉ imi Kudret hocama anlattēn.

Hocam, sen Almanca biliyor musun diye sordu ve merakla daktilodaki sayfayēçēartē tez ile karkēakēearak

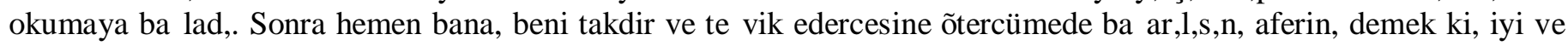
sürekli çalēđēēèsa, 9-10 ayda da, bir Keyler öj renilebiliyor, aferinò dedi.

Tabii ki, benim için bu takdir, altê̄ deĵ erinde bir diploma ya da ödül idi. Kadere bakēèè ki, yëlar sonra Üniversitelerarasē Kurul tarafēèdan olukurulan Yabancē Dil Doçentlik Sēnavēnda Kudret Ayiter hocam K̦stanbul Hukuk Fakültesinde ö̂̀ retim üyesi olan Prof. Dr. Bülent Davran ve Ankara Üniversitesi Hukuk Fakültesi ọ̈̂ retim üyelerinden Prof. Dr. Hüseyin Cahit Oĵ uzô̂ lu ile birlikte jüri üyesi olarak Almanca yabancēdil sênavēnēyaptē

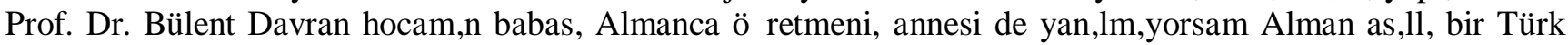
vatandakēidi. DüKinün ki, iki Alman asథ̄lēTürk vatandaKēkikinin deĵ erli hukuk profesörü oĵ ullarēbenim Almanca YabancēDil Doçentlik Sēenavēnda üye olarak bulunmuklardē Prof. Dr. Hüseyin Cahit Oĵ uzộ lu hocamēền Almancasē da iyiydi ama, Almanca, dî̄ er iki hocamēi ana dilleriydi.

Ve ben, doçentlik yabancēdil sēevēēēböyle bir jüri huzurunda bakarēella kazandēn. Ķরe yëlar önce, daha ikin

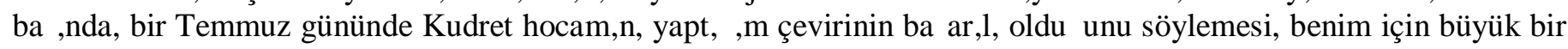
moral olmuku. Çünkü, yaptệ̂ ên tercümenin doĵru ve yeterli olup olmadệ̂ẹē o zamanlar bakka hiç kimseye sormamēè̄èn, soramazdēn da, bu tesadüf benim bakarēnēe ilk kilometre takēolmuku.

Gerçekten de, Kudret Hocamēè olumlu görüKui, beni o konuda yücelten, umutlandēan ilk teKvik ödülü oldu.

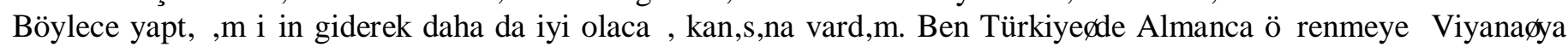
gidinceye kadar devam ettim. Viyanaôa Prof. Gürsoy hocamēe sözünü tuttum ve bekâr olarak gittim ve 2 y $\nexists$ orada kaldēn. Viyanaôlan döndükten sonra da doçent olmaya yakē̄ evlendim. Gürsoy hocamēè bütün tavsiyelerini tuttum, öj ütlerini yerine getirdim. Askere de doçent olduktan sonra gittim.

Almanca, Fransēèca ve Ķgilizce biliyorum. Almanca ö̂̂ renmek için Türkiyeâleki çalērmalarēn dēēênda 1963-

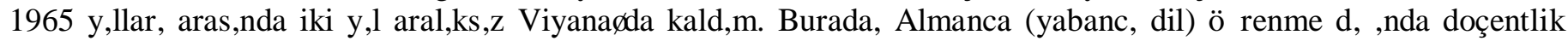

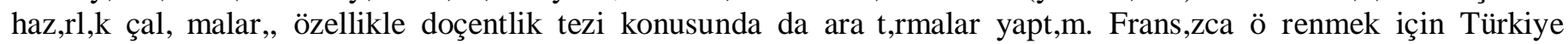

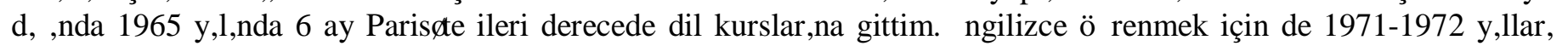

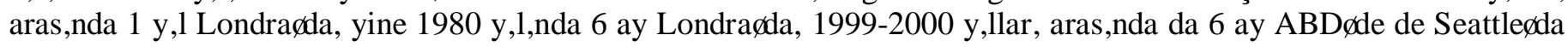
kaldēn.

Hukuk yayēllarēn arasēida özellikle, Türk Medeni Hukukunda Ölüme Bâ̂l lēTasarruflarē łptali Davasēadlē doktora tezimi (1966 yēē, Türk Medeni Hukukunda Tenkis Davasēadlēdoçentlik tezimi (1973 yēē, Sorumluluk Hukuku Açēēèdan Uygun K̦liyet Bậ ēadlēprofesörlük tezimi (1985 yēē, 1367 sayfalæ Borçlar Hukuku Genel Hükümler (23. Baskēe 2018) adlē kitabēnē 1056 sayfalę Borçlar Hukuku, Özel Hükümler (6. Baskẹ 2018) adlē kitabēnē 527 sayfalđ Mülkiyet Hukuku (5. Baskē 2018) adlē kitabēnēe, 661 sayfalēk Türk Miras Hukuku (2019, Doç. Dr. Kạek Yücer Aktürk ile ortak eser) adlēkitabēnē Toprak Hukuku adlē375 sayfalę kitabēnē(5. Baskē2017, sonradan Prof. Dr. Veysel Bałpē literatürüne geçmik ve birçok hukuk fakültesinde okutulan bu kitaplar dēēēda Türkçe ve Almanca say $\bar{\Theta} \bar{\Theta}$ hukuk makaleleri ve teblij lerim yayēnlanmēè $\bar{e}$.

Hiç kukkusuz, Türkiyeôin sorunlarēella da ilgileniyorum. Atatürk ilkelerine baĵ lẹ hukukun üstünlüj üne ve

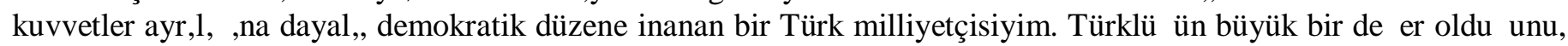
büyük bir kültür olduĵ unu düKinüyorum. Türk Devletini (TCôji), Türk vatanēnēe Türk milletimi, Türk bayraĵ ênē Türk dilini seviyorum. ñNe mutlu Türküm diyeneòilkesine bâj lệền. Tam anlamēèla Türk kültürünü yakēerom. Türk üniversitelerinin en ulularēèdan biri olan çok deĵ erli, yüksek düzeyli Ankara Üniversitesi Hukuk Fakültesinde 19542002 yẻlarēarasēêda hukuk öj rencisi ve medeni hukuk anabilim dalēida öô retim üyesi olarak çalēêện için onur ve 
gurur duyuyorum. Daha sonra da 16 yēdan beri Ankara@̂la Bakkent Üniversitesinde medeni hukuk anabilim dalēenda ôj retim üyesi olarak çalēđề ēn için yine gurur duyuyorum.

Ö̂̀ renci, asistan, doçent, profesör oldum. Kural olarak her gün 10 saat çalētền. Bence akēe, çalēermadēe $\mathrm{Ne}$ kadar çok çalēēèsan, o kadar çok akēlēelursun. Ķ̣sanda aklēyapan, kuran ve koruyan çalēemadēe

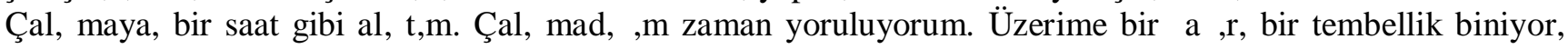
kötümser oluyorum, adeta kendimi görevini yapmamēe bir insan olarak görüyorum. Oysa çalēđề ēn zaman bir kahin, bir kartal oluyorum. Hiç doymuyorum çalēemaya. Yüzlerce yüksek lisans (master), doktora tezi yönettim. On binlerce hukuk öĵrencisi, avukat, hakim, savcē noter, doçent, profesör yetikirdim. Hepsi de iyi hukukçu oldular. Bunlarēe yetikmelerinde pay sahibi oldujum için büyük bir onur ve gurur duymaktayēn. Her yönden kanslē olduĵ umu düKinüyorum. Bu kans ve onuru bana verdî̄ i için Yüce Allahôa hamd ve Kikürler ediyorum.

Bana, kendimi anlatma imkanē verdî̂ i için Ķönü Üniversitesi Hukuk Fakültesi Dekanē Prof. Dr. Haluk Emirộ luôna, ọ̈̂ retim üyelerine ve bu röportajēgerçeklektiren Dekan YardēncēēēDr. Öĵr. Üyesi Adem Yelmen⿳̂巛 sonsuz tekekkürlerimi sunuyorum. 